\title{
HUBUNGAN ANTARA PENGETAHUAN DAN SIKAP TERHADAP PERILAKU DALAM PENGENDALIAN VEKTOR DEMAM BERDARAH DENGUE (DBD) DI DESA JELOK CEPOGO BOYOLALI
}

\author{
Sri Sayekti Heni Sunaryanti ${ }^{1, *}$, Sri Iswahyuni². \\ ${ }^{1,2}$ STIKES Mamba'ul 'Ulum Surakarta \\ ${ }^{1}$ ss.heni.s29@gmail.com*
}

\begin{abstract}
Abstrak
Latar belakang: Penyakit Demam Berdarah Dengue (DBD) yang biasa disebut Dengue Haemorrahagic Fever (DHF) adalah penyakit yang disebabkan oleh virus dengue yang ditularkan melalui nyamuk Aedes Aegypti dan aedes Albopictus. Jumlah penderita DBD pada tahun 2014 sebanyak 100.347 orang, tahun 2015 meningkat sebanyak 129.650. Pada tahun 2016 sebanyak 204.171, pada tahun 2017 jumlah penderita menurun menjadi 68.407. Tahun 2018 sebanyak 53.075 kemudian ditahun 2019 ini sebanyak 13.683 (Kemenkes RI, 2019). Berdasarkan data dari Subdin Pencegahan dan Pemberantasan Penyakit (P2P) DKK Boyolali, dari bulan Januari sampai dengan Desember 2018 terdapat 7 penderita DBD. Sehingga diperlukan langkah-langkah pencegahan serta kewaspadaan terhadap peningkatan kasus DBD.

Tujuan: Mengetahui hubungan pengetahuan dan sikap terhadap perilaku masyarakat dalam pengendalian vektor Demam Berdarah Dengue di desa Jelok, Kecamatan Cepogo, Kabupaten Boyolali.

Metode: Jenis penelitian ini adalah analitik korelasional dengan rancangan Cross Sectional. Populasi sebanyak 51 orang dan sampel diambil dengan purposive sampling sebanyak 33 responden. Data pengetahuan, sikap dan perilaku diperoleh dengan menggunakan kuesioner. Analisa data dengan menggunakan analisis Rank-Spearman.
\end{abstract}

Hasil: (1) Tingkat pengetahuan responden kurang baik: 21,20\%, pengetahuan cukup baik: 42,40\% dan pengetahuan baik: 36,40\%; (2) Sikap responden tergolong kurang baik: 9,10\%, cukup baik: 66,70\% dan sikap baik: 24,20\%; (3) Perilaku responden tergolong kurang baik: $27,30 \%$, cukup baik: $39,40 \%$ dan perilaku baik: 33,33\%; (4) Berdasarkan analisis rank spearman diketahui terdapat hubungan yang signifikan pengetahuan dan sikap dengan perilaku masyarakat dalam pengendalian vektor demam berdarah dengue di Desa Jelok, Cepogo, Boyolali, dengan nilai probabilitas $\left(r_{\mathrm{x} 1 \mathrm{y}}=0,346 ; p_{1}=0,048\right.$ dan $\left.r_{x 2 y}=0,393 ; p_{2}=0,024\right)$.

Simpulan: Terdapat hubungan yang signifikan pengetahuan dan sikap dengan perilaku masyarakat dalam pengendalian vektor demam berdarah dengue di Jelok, Cepogo, Boyolali.

Kata kunci: Pengetahuan; Sikap; Perilaku; Vektor Demam Berdarah Dengue 


\title{
RELATIONSHIP BETWEEN KNOWLEDGE AND ATTITUDE TOWARD BEHAVIOR IN THE CONTROL OF DENGUE HEMORRHAGIC FEVER (DHF) IN JELOK CEPOGO BOYOLALI
}

\begin{abstract}
Background: Dengue Hemorrhagic Fever (DHF) commonly called Dengue Haemorrahagic Fever (DHF) is a disease caused by dengue virus transmitted through the Aedes Aegypti and Albopictus aedes mosquitoes. The number of DHF sufferers in 2014 was 100,347 people, in 2015 an increase of 129,650. In 2016 as many as 204,171, in 2017 the number of sufferers decreased to 68,407. In 2018 there were 53,075, then in 2019 there were 13,683 (Ministry of Health Republic of Indonesia, 2019). Based on data from the Disease Prevention and Eradication Subdivision (P2P) Boyolali DKK, from January to December 2018 there were 7 patients with DHF. So that necessary preventative measures and vigilance against an increase in dengue cases.
\end{abstract}

Objective: To determine the relationship of knowledge and attitudes towards community behavior in controlling Dengue Hemorrhagic Fever vector in Jelok village, Cepogo District, Boyolali Regency.

Method: This type of research is a correlational analytic study with a crosssectional design. The population was 51 people and the sample was taken by purposive sampling of 33 respondents. Knowledge, attitude and behavior data were obtained using a questionnaire. Data analysis using Rank-Spearman analysis.

Results: (1) The level of knowledge of respondents is $21.20 \%$, knowledge was quite good is $42.40 \%$ and good knowledge is 36.40\%; (2) Respondents' attitudes are classified as not good is $9.10 \%$, good enough is $66.70 \%$ and good attitudes is 24.20\%; (3) Respondent's behavior is not good enough is $27.30 \%$, good enough is $39.40 \%$ and good behavior is 33.33\%; (4) Based on Spearman rank analysis, it is known that there is a significant relationship between knowledge and attitude with community behavior in controlling dengue vector in Jelok, Cepogo, Boyolali, with probability values $(r x 1 y=0.346 ; p 1=0.048$ and $r x 2 y=0.393 ; p 2=0.024)$.

Conclusion: There is a significant relationship between knowledge and attitude with people's behavior in controlling dengue vector in Jelok, Cepogo, Boyolali.

Keywords: Knowledge; Attitude; Behavior; Dengue Hemorrhagic Fever Vector

\section{PENDAHULUAN}

Penyakit Demam Berdarah Dengue (DBD) atau Dengue Haemorhagic Fever (DHF) yang biasa disebut Dengue Haemorrahagic Fever (DHF) adalah penyakit yang disebabkan oleh virus dengue yang ditularkan melalui nyamuk Aedes Aegypti dan Aedes Albopictus. Penyakit ini merupakan salah satu dari beberapa penyakit menular yang menjadi masalah kesehatan di dunia terutama negara-negara berkembang. Jumlah penderita DBD pada tahun 2014 sebanyak 100.347 orang, tahun 2015 meningkat sebanyak 129.650. Pada tahun 2016 sebanyak 204.171, pada tahun 2017 jumlah penderita menurun menjadi 68.407. Tahun 2018 sebanyak 53.075 kemudian ditahun 2019 ini 
sebanyak 13.683 (Kemenkes RI, 2019). Memasuki awal tahun 2019 di Indonesia, jumlah kasus penyakit DBD mengalami peningkatan yang cukup bermakna dari tahun ke tahun. Berdasarkan Laporan dari 34 propinsi bahwa mulai 01 hingga 29 Januari 2019 tercatat terjadi 13.683 kasus DBD dan penderita yang tidak tertolong sebanyak 133 jiwa. Berdasarkan data dari Subdin Pencegahan dan Pemberantasan Penyakit (P2P) DKK Boyolali, dari bulan Januari sampai dengan Desember 2018 terdapat 7 penderita DBD. Banyak faktor yang mempengaruhi kejadian penyakit Demam Berdarah Dengue (DBD). Diantara adalah faktor inang (host), lingkungan (environment) dan faktor penular serta patogen (virus) (Wijaya AS\&Putri YM, 2013).

Sehingga diperlukan Upaya pencegahan dan pengendalian penyakit DBD ini. Salah satu upayanya adalah dengan terus menggalakkan upaya pemberantasan sarang nyamuk (PSN) plus dan fogging.

Menurut Notoatmodjo (2012), pengetahuan adalah merupakan hasil "tahu", dan ini terjadi setelah orang melakukan penginderaan terhadap suatu objek tertentu. Penginderaan terjadi melalui pancaindera manusia, yaitu: indra penglihatan, pendengaran, penciuman, rasa, dan raba. Sebagian besar pengetahuan manusia diperoleh melalui mata dan telinga. Pengetahuan atau kognitif merupakan domain yang sangat penting untuk terbentuknya tindakan seseorang (overt behavior).

Sikap menurut Notoatmodjo (2014) adalah merupakan reaksi atau respon seseorang yang masih tertutup terhadap suatu stimulus atau objek. Jadi, sikap merupakan reaksi atau respon yang masih tertutup dari seseorang terhadap suatu stimulus atau objek.

Menurut Bloom (cit Notoatmojo, 2012) perilaku seseorang terdiri dari tiga bagian yaitu ranah kognitif, ranah afektif, ranah psikomotor. Dalam perkembangannya teori Bloom ini dimodifikasi untuk pengukuran hasil pendidikan kesehatan yaitu pengetahuan (Knowledge), sikap (attitude), dan praktek atau tindakan (Pratice).

Berdasarkan uraian di atas, dapat ditegaskan bahwa sikap dan pengetahuan adalah merupakan respons seseorang terhadap stimulus (rangsangan) yang masih bersifat terselubung (covert behavior) sedangkan tindakan nyata seseorang sebagai respons terhadap stimulus (practicelovert behavior) (Notoatmodjo, 2012).

Penyakit DBD disebabkan oleh virus dengue (termasuk group B Arthropod borne virus), merupakan bagian dari famili Flaviviridae, genus Flavivirus, melalui perantara (vektor) nyamuk aedes aegypti (paling sering) dan jarang oleh aedes albopictus (Wijaya AS\& Putri YM, 2013).

Dalam rangka pembinaan dan peningkatan perilaku kesehatan masyarakat, tampaknya pendidikan kesehatan dipandang lebih tepat bila dibandingkan dengan pendekatan yang lain. Pendidikan kesehatan adalah suatu bentuk intervensi atau upaya yang ditujukan kepada perilaku, agar perilaku tersebut kondusif untuk kesehatan (Notoatmodjo, 2014). Di dalam proses pembentukan dan atau perubahan, perilaku dipengaruhi oleh beberapa fkator yang beradal dari dalam dari dari luar individu itu sendiri. Faktor-faktor tersebut antara lain: susunan syaraf pusat, persepsi, motivasi, 
emosi, proses belajar, lingkungan, dan sebagainya.

Susunan syaraf pusat memegang peranan penting dalam perilaku manusia, karena merupakan sebuah bentuk perpindahan dari rangsangan yang masuk menjadi perbuatan atau tindakan. Perpindahan ini dilakukan oleh susunan syaraf pusat dengan unit-unit dasarnya yang disebut neuron. Neuron memindahkan energi-energi di dalam impuls-impuls syaraf. Impuls-impuls syaraf indra pendengaran, penglihatan, pembauan, pencecepan, dan perabaan disalurkan dari tempat terjadinya rangsangan melalui impuls-impuls syaraf ke susunan syaraf pusat.

\section{METODE}

Jenis Penelitian yang digunakan adalah deskriptif analitik. Menggunakan pendekatan cross sectional karena dilaksanakan hanya sekali pada saat/waktu tertentu saja (Setiadi, 2013). Populasi sebanyak $51 \mathrm{KK}$ sedang jumlah sampel penelitian sebanyak $33 \mathrm{KK}$. Alat dan metode pengumpulan data berupa kuesioner. Analisis data menggunakan Rank-Spearman.

\section{HASIL DAN PEMBAHASAN}

Tabel 1. Distribusi frekuensi responden menurut umur

\begin{tabular}{ccc}
\hline Umur & Frekuensi & Persentase $(\%)$ \\
\hline$<30$ tahun & 8 & 24,20 \\
$30-33$ tahun & 8 & 24,20 \\
$>33$ tahun & 17 & 51,50 \\
Total & 33 & 100,00 \\
\hline
\end{tabular}

Sumber: Data primer yang diolah

Berdasarkan tabel 1 dapat diketahui bahwa umur responden kurang dari 30 tahun sebanyak 8 orang $(24,20 \%)$, umur antara 30-33 tahun sebanyak 8 orang $(24,20 \%)$, dan umur lebih dari 33 tahun sebanyak 17 orang $(51,50 \%)$, jadi kebanyakan responden berumur lebih dari 33 tahun $(51,50 \%)$ dari keseluruhan responden.

Tabel 2. Distribusi frekuensi pendidikan Terakhir.

\begin{tabular}{ccc}
\hline Pendidikan akhir & Frekuensi & Persentase (\%) \\
\hline SD & 14 & 42,40 \\
SLTP & 8 & 24,20 \\
SLTA & 4 & 12,10 \\
Akademi/PT & 2 & 6,10 \\
Tidak sekolah & 5 & 15,20 \\
Total & 33 & 100,00 \\
\hline
\end{tabular}

Sumber: Data primer yang diolah

Berdasarkan Tabel 2 tersebut dapat diketahui bahwa kebanyakan responden mempunyai pendidikan akhir SD yaitu 14 orang $(42,40 \%)$ dari keseluruhan 
responden. SLTP: 8 orang (24,20\%), SLTA: 4 orang (12,10\%), Akademi/PT: 5 orang $(6,10 \%)$ dan tidak sekolah: 5 orang $(15,20 \%)$.

Tabel 3. Distribusi frekuensi menurut jenis pekerjaan

\begin{tabular}{ccc}
\hline Jenis Kelamin & Frekuensi & Persentase (\%) \\
\hline Petani/Nelayan & 16 & 48,50 \\
Pedagang & 7 & 21,20 \\
PNS/ABRI & 2 & 6,10 \\
Tidak bekerja/IRT & 8 & 24,20 \\
Total & 33 & 100,00 \\
\hline
\end{tabular}

Sumber: Data primer yang diolah

Berdasarkan Tabel 3 diketahui kebanyakan responden dilihat dari jenis pekerjaan kebanyakan adalah petani yaitu sebanyak 16 orang (48,5\%). Hal ini disebabkan karena daerah tersebut merupakan area atau daerah pertanian yang cukup luas serta pengairan yang cukup.

Tabel 4: Distribusi frekuensi responden menurut Pengetahuan

\begin{tabular}{ccc}
\hline Sikap & Frekuensi & Persentase (\%) \\
\hline Kurang baik & 7 & 21,20 \\
Cukup baik & 14 & 42,40 \\
Baik & 12 & 36,40 \\
Total & 33 & 100,00 \\
\hline
\end{tabular}

Sumber: Data primer yang diolah

Berdasarkan Tabel 4 diketahui bahwa responden mempunyai pengetahuan kurang baik sebanyak 7 orang $(21,20 \%)$, pengetahuan cukup baik sebanyak 14 orang $(42,40 \%)$ dan pengetahuan baik sebesar 12 orang $(36,40 \%)$ dari keseluruhan responden.

Tabel 5. Distribusi frekuensi responden menurut Sikap

\begin{tabular}{ccc}
\hline Sikap & Frekuensi & Persentase (\%) \\
\hline Kurang baik & 3 & 9,10 \\
Cukup baik & 22 & 66,70 \\
Baik & 8 & 24,20 \\
Total & 33 & 100,00
\end{tabular}

Sumber: Data primer yang diolah

Berdasarkan Tabel 5 diketahui bahwa responden yang mempunyai sikap kurang baik ada 3 orang $(9,10 \%)$, cukup baik sebanyak 22 orang $(66,70 \%)$ dan sikap baik hanya sebesar 8 orang $(24,20 \%)$ dari keseluruhan responden.

Tabel 6. Distribusi frekuensi responden menurut Perilaku

\begin{tabular}{lcc}
\hline Perilaku & frekuensi & Persentase $(\%)$ \\
\hline
\end{tabular}




\begin{tabular}{ccc}
\hline Kurang baik & 9 & 27,30 \\
Cukup baik & 13 & 39,40 \\
Baik & 11 & 33,33 \\
Total & 33 & 100,00 \\
\hline
\end{tabular}

Sumber: Data primer yang diolah

Tabel 6 diketahui bahwa responden yang mempunyai perilaku kurang baik sebanyak 9 orang $(27,30 \%)$, cukup baik sebanyak 13 orang $(39,40 \%)$ dan perilaku baik hanya sebesar 11 orang $(33,33 \%)$ dari keseluruhan responden.

Tabel 7.Tabel Silang Pengetahuan dengan perilaku pengendalian vektor demam berdarah dengue

\begin{tabular}{cccccc}
\hline \multirow{2}{*}{ Pengetahuan } & \multicolumn{4}{c}{ Perilaku } \\
\cline { 3 - 6 } Kurang & Count & Kurang baik & Cukup baik & Baik & Total \\
baik & \% of Total & $9.10 \%$ & $3.00 \%$ & $9.10 \%$ & $21.20 \%$ \\
Cukup baik & Count & 4 & 6 & 4 & 14 \\
& \% of Total & $12.10 \%$ & $18.20 \%$ & $12.10 \%$ & $42.40 \%$ \\
\multirow{3}{*}{ Baik } & Count & 2 & 6 & 4 & 12 \\
& \% of Total & $6.10 \%$ & $18.20 \%$ & $12.10 \%$ & $36.40 \%$ \\
\multirow{2}{*}{ Total } & Count & 9 & 13 & 11 & 33 \\
& \% of Total & $27.30 \%$ & $39.40 \%$ & $33.30 \%$ & $100.00 \%$ \\
\hline
\end{tabular}

Sumber: Data primer yang diolah

Setelah dilakukan pengumpulan menurut nilai analisis silang (crosstabulasi) jawaban tentang "pengetahuan dengan perilaku pengendalian" diketahui bahwa pengetahuan kurang baik dan perilaku pengendalian kurang baik sebanyak 3 orang $(9,10 \%)$, pengetahuan kurang baik dengan perilaku pengendalian cukup baik sebanyak 1 orang $(3,0 \%)$, pengetahuan kurang baik dengan perilaku pengendalian baik 3 orang $(9,10 \%)$, responden yang mempunyai pengetahuan cukup baik dengan perilaku pengendalian kurang baik sebanyak 4 orang $(12,10 \%)$, mempunyai pengetahuan cukup baik dengan perilaku pengendalian cukup baik sebanyak 6 orang $(18,20 \%)$, dan pengetahuan cukup baik dengan perilaku pengendalian baik sebanyak 4 orang $(12,10 \%)$. Sedangkan yang mempunyai pengetahuan baik dengan perilaku pengendalian kurang baik tidak ada 2 orang $(6,10 \%)$, pengetahuan baik dengan perilaku pengendalian cukup baik sebanyak 6 orang $(18,20 \%)$ dan yang mempunyai pengetahuan baik dengan perilaku pengendalian baik sebanyak 4 orang $(12,10 \%)$ dari keseluruhan responden.

Berdasarkan hasil tersebut dapat diketahui bahwa ternyata responden yang mendominasi adalah yang mempunyai pengetahuan baik dengan perilaku pengendalian cukup baik yaitu sebanyak 6 orang $(18,20 \%)$ dari keseluruhan responden. 
Tabel 8. Tabel silang Sikap dengan perilaku pengendalian vektor demam berdarah dengue

\begin{tabular}{cccccc}
\hline \multirow{2}{*}{ Sikap } & \multicolumn{4}{c}{ Perilaku } \\
\cline { 3 - 6 } & & Kurang baik & Cukup baik & Baik & Total \\
\hline Kurang & Count & 0 & 1 & 2 & 3 \\
baik & \% of Total & $0.00 \%$ & $3.00 \%$ & $6.10 \%$ & $9.10 \%$ \\
Cukup & Count & 7 & 8 & 7 & 22 \\
baik & \% of Total & $21.20 \%$ & $24.20 \%$ & $21.20 \%$ & $66.70 \%$ \\
& Count & 2 & 4 & 2 & 8 \\
Baik & \% of Total & $6.10 \%$ & $12.10 \%$ & $6.10 \%$ & $24.20 \%$ \\
& Count & 9 & 13 & 11 & 33 \\
Total & \% of Total & $27.30 \%$ & $39.40 \%$ & $33.30 \%$ & $100.00 \%$ \\
\hline
\end{tabular}

Sumber: Data primer yang diolah

Tabel 9. Hasil Analisis Korelasi Rank-Spearman: pengetahuan dengan Perilaku Correlations

\begin{tabular}{ccc}
\hline Spearman's rho & Pengetahuan & Perilaku \\
\hline Pengetahuan Correlation Coefficient & 1 & $.346^{*}$ \\
Sig. (2-tailed) N & .33 & 0.048 \\
& & 33 \\
Perilaku Correlation Coefficient & $.346^{*}$ & 1 \\
Sig. (2-tailed) N & 0.048 & .33 \\
& 33 & \\
\hline
\end{tabular}

*. Correlation is significant at the 0.05 level (2-tailed).

Hubungan antara pengetahuan dengan perilaku pencegahan penyakit demam berdarah dengue. Berdasarkan hasil analisis Rank-Spearman diketahui adanya hubungan positif antara pengetahuan dengan perilaku pencegahan dalam pencegahan penyakit demam berdarah dengue di Desa Jelok, Kecamatan Cepogo, Kabupaten Boyolali. Hasil perhitungan nilai RankSpearman sebesar 0,346 dengan tingkat signifikan 0,048, dimana tingkat signifikan lebih kecil dari 0,05 maka dapat dikatakan bahwa terdapat hubungan yang signifikan antara pengetahuan dengan perilaku pencegahan penyakit demam berdarah dengue di Desa Jelok, Kecamatan Cepogo, Kabupaten Boyolali.

Berdasarkan hasil analisis hubungan antara pengetahuan dengan perilaku dalam pengendalian vektor demam berdarah dengue mempunyai hubungan yang signifikan. Hal ini berarti bahwa dengan tingkat pengetahuan yang dimiliki responden akan berhubungan dengan perilaku dalam pengendalian penyakit demam berdarah dengue. Semakin tinggi tingkat pengetahuan responden maka perilaku responden terhadap vektor demam berdaah dengue semakin baik pula. 
Tabel 10. Hasil Analisis Korelasi Rank-Spearman: Sikap dengan perilaku Correlations

\begin{tabular}{cccc}
\hline karakteristik & Spearman's rho & Perilaku & Sikap \\
\hline \multirow{2}{*}{ Perilaku } & Correlation Coefficient & 1 & $.393^{*}$ \\
& Sig. (2-tailed) N &. & 0.024 \\
\multirow{2}{*}{ Sikap } & Correlation Coefficient Sig. (2-tailed) & $.393^{*}$ & 33 \\
& N & 0.024 & 1 \\
& & 33 &. \\
& &
\end{tabular}

*. Correlation is significant at the 0.05 level (2-tailed).

Berdasarkan hasil analisis Rank-Spearman mengisyaratkan adanya hubungan positif dan signifikan antara sikap dengan perilaku pencegahan penyakit demam berdarah dengue. Hasil perhitungan nilai Rank-Spearman sebesar 0,393 dengan tingkat signifikan 0,024, dimana tingkat signifikan kurang dari 0,05, sehingga dapat dikatakan bahwa terdapat hubungan yang berarti antara sikap dengan perilaku pencegahan penyakit demam berdarah dengue di Desa Jelok, Cepogo, Boyolali.

Berdasarkan hasil analisis yang telah dilakukan, maka dapat diterangkan hubungan antara pengetahuan dengan perilaku pencegahan penyakit demam berdarah dengue di Desa Jelok, Cepogo, Boyolali dan hubungan antara sikap dengan perilaku pencegahan penyakit demam berdarah dengue di Desa Jelok, Cepogo, Boyolali sebagai berikut:

1. Hubungan antara pengetahuan dengan perilaku masyarakat dalam pencegahan penyakit Demam Berdarah Dengue

Berdasarkan hasil analisis Rank-Sparman diketahui adanya hubungan yang berarti antara pengetahuan dengan perilaku masyarakat dalam pencegahan penyakit demam berdarah dengue di Desa Jelok, Cepogo, Boyolali Hasil perhitungan nilai Rank-Spearman sebesar 0,346 yang tergolong mempunyai hubungan yang cukup erat dengan tingkat signifikan 0,048, hal ini dapat dikatakan bahwa terdapat hubungan yang berarti antara pengetahuan masyarakat dengan perilaku pencegahan terhadap penyakit demam berdarah dengue di Desa Jelok, Cepogo, Boyolali.

Hal ini sesuai dengan teori yang dikemukakan oleh Ditjen P2P, KemenKes. RI (2018), pengetahuan tentang demam berdarah dengue baik yang menyangkut masalah penyebab, pencegahan dan pengobatannya perlu diketahui oleh semua orang termasuk anggota keluarga, guna menghindari terjadinya penyakit demam berdarah. Menurut Notoatmodjo (2012), pengetahuan yang tercakup dalam domain kognitif mempunyai 6 tingkatan: 1) tahu, 2) memahami, 3) aplikasi, 4) analisis, 5) sintesis, dan 6) evaluasi. Hal ini membuktikan bahwa responden dengan tingkat pengetahuan yang cukup baik akan mempunyai perilaku terhadap pencegahan penyakit demam berdarah dengue yang baik pula.

Hasil penelitian menunjukkan bahwa jumlah responden pada rentang usia paling banyak diantara responden lainnya yang mempunyai rentang usia lebih muda. Daya tangkap dan pola pikir seseorang terhadap suatu objek akan meningkat seiring dengan bertambahnya usia sehingga pengetahuan yang 
diperolehnya semakin membaik (Notoatmodjo, 2012). Bertambahnya informasi tentang suatu objek menjadikan salah satu hal yang dapat membentuk sikap seseorang (Azwar, 2011).

Adapun faktor-faktor yang mempengaruhi pengetahuan menurut Notoatmodjo (2012) diantaranya pendidikan, informasi/media massa, pekerjaan, lingkungan, pengalaman, usia, sosial, budaya dan ekonomi.

Pendidikan merupakan salah satu faktor yang mempengaruhi seseorang dalam proses belajar, semakin tinggi pendidikan seseorang maka semakin mudah orang tersebut menerima berbagai informasi dan meningkatkan pengetahuan (Budiman dan Riyanto, 2013).

Azwar (2011) menyatakan bahwa terdapat beberapa faktor yang mempengaruhi pembentukan sikap seseorang, antara lain pengalaman pribadi, pengaruh orang lain, kebudayaan, media massa dan faktor emosional.

Selain itu, faktor yang dapat mempengaruhi sikap masyarakat adalah pengaruh orang lain yaitu ketika seseorang memiliki sikap negatif, orang tersebut dapat memiliki sikap positif ketika terpengaruh oleh orang lain yang memiliki sikap positif dalam perilaku pencegahan penyakit Demam Berdarah Dengue.

Handayani (2015) juga menyatakan bahwa terdapat hubungan yang bermakna antara tingkat pengetahuan tentang seks dengan sikap siswa SMAN 1 Kandanghaur terhadap seks pranikah, meskipun keeratan hubungan dinyatakan lemah.

Hasil dalam penelitian ini sesuai dengan penelitian yang dilakukan Fitriani dan Andriyani (2015) yang menyatakan bahwa tidak ada hubungan antara pengetahuan dengan sikap anak usia sekolah akhir (10-12 tahun) tentang makanan jajanan (nilai $p$ value $=0,065$ ).

2. Hubungan antara sikap dengan perilaku masyarakat terhadap pencegahan penyakit demam berdarah dengue

Berdasarkan hasil analisis Rank-Spearman mengisyaratkan adanya hubungan positif antara sikap dengan perilaku masyarakat terhadap pencegahan penyakit demam berdarah dengue di Desa Jelok, Cepogo, Boyolali Hasil perhitungan nilai Rank-Spearman sebesar 0,393 yang tergolong mempunyai hubungan yang cukup erat dengan tingkat signifikan 0,024, dimana tingkat signifikan kurang dari 0,05 maka dapat dikatakan bahwa terdapat hubungan yang berarti antara sikap dengan perilaku masyarakat terhadap pencegahan penyakit demam berdarah dengue di Desa Jelok, Cepogo, Boyolali.

Hasil penelitian ini didukung oleh hasil distribusi frekuensi jawaban tentang "sikap" diketahui bahwa sikap yang cukup baik sebanyak 22 orang $(66,7 \%)$, mempunyai sikap kurang baik sebanyak 3 orang $(9,10 \%)$, dan mempunyai sikap baik seanyak 12 orang $(36,40 \%)$, berdasarkan hasil tersebut dapat diketahui bahwa kebanyakan responden mempunyai sikap yang cukup baik (14 orang atau 42,40\%) tentang penyakit demam berdarah dengue dari keseluruhan responden. Hal ini berarti bahwa sikap masyarakat dalam mendukung pemgendalian penyakit demam berdarah dengue cukup dapat bertindak, berpersepsi, dan berpikir serta cukup mempunyai kesadaran dan ketanggapan serta kecepatan dalam menangani dan mendukung proses 
pencegahan penyakit demam berdarah dengue di Desa Jelok, Cepogo, Boyolali

Banyak faktor yang mempengaruhi sikap masyarakat tergantung dari faktor yang mempengaruhinya, bukan hanya dari faktor pengetahuan namun dapat juga dari faktor lainnya seperti, pengalaman pribadi, pengaruh orang lain, atau kebudayaan di lingkungan (Azwar, 2011).

Berdasarkan penjelasan di atas, sesuai teori yang dikemukakan oleh Notoatmodjo (2014), yang mendefinisikan sikap sebagai berikut:

a) Sikap adalah kecenderungan bertindak, berpersepsi, berpikir, dan merasa dalam menghadapi objek, ide, situasi atau nilai. Sikap bukan perilaku, tetapi merupakan kecenderungan untuk berperilaku dengan cara- cara tertentu terhadap objek sikap, b) Sikap mengandung aspek evaluatif artinya mengandung nilai menyenangkan, nilai tidak menyenangkan, dan c) Sikap timbul dari pengalaman, tidak di bawa sejak lahir tetapi merupakan hasil belajar.

Hasil penelitian ini sesuai dengan hasik Penelitian Ristiyanto, dkk (2013) yang menyatakan bahwa penyuluhan kesehatan serta penyebaran leaflat, poster dan baliho dapat meningkatkan pengetahuan masyarakat Kabupaten Bantul tentang pencegahan leptospirosis.

Pengetahuan masyarakat tentang pengendalian vektor Demam Berdarah Dengue dapat dipengaruhi oleh banyak faktor. Salah satunya ialah informasi dari media cetak maupun media elektronik. Budiman \& Riyanto (2013) mengatakan bahwa adanya informasi baru mengenai suatu hal memberikan landasan kognitif baru bagi terbentuknya pengetahuan terhadap hal tersebut. Hasil penelitian Sari dan Ismail (2012) menguatkan bahwa terdapat hubungan yang bermakna antara informasi yang didapat terhadap pengetahuan remaja tentang HIV-AIDS dengan nilai $\mathrm{p}=0.001$.

Berdasarkan pendapat tersebut dapat diimplikasikan bahwa dengan dimilikinya sikap yang baik yang umumnya timbul dari pengalaman, baik pengalaman yang baik maupun yang buruk, suatu masyarakat khususnya kepala keluarga atau anggota keluarga akan baik pula terhadap perilaku pengendalian vektor demam berdarah khususnya masyarakat di Desa Jelok, Cepogo, Boyolali. Seorang anggota masyarakat yang mempunyai kepedulian terhadap lingkungan, baik itu yang mempunyai tingkat pendidikan rendah maupun tinggi serta pekerjaan apa yang dimilikinya, dimungkinkan akan mempunyai sikap terhadap kejadian-kejadian yang terjadi di lingkungan sekitarnya, demikian halnya sikap terhadap tindakan pengendalian pencegahan penyakit demam berdarah dengue.

Peningkatan pengetahuan, sikap, dan PSN di masyarakat dapat meningkatkan upaya pengendalian vektor DBD sehingga angka kasus DBD di Kota Bandung dapat ditekan. Hal ini sejalan dengan hasil penelitian di Kabupaten Blora yang menyatakan bahwa pengetahuan, sikap, ketersediaan informasi, dan peran petugas kesehatan adalah faktor-faktor yang mempengaruhi perilaku PSN DBD (Listyorini,2016).

Upaya lain dengan modifikasi upaya pengendalian vektor dengan membentuk jumantik tingkat keluarga yaitu dengan memilih anggota rumah 
tangga yang tidak terlalu disibukkan dengan kegiatan di luar rumah sehingga diharapkan jumantik tersebut dapat maksimal melakukan upaya pemantauan vektor DBD.

\section{SIMPULAN}

Berdasarkan hasil pengamatan dan analisis data, maka dapat disimpulkan sebagai berikut: 1). Tingkat pengetahuan responden kurang baik sebanyak 7 orang $(21,20 \%)$, pengetahuan cukup baik sebanyak 14 orang $(42,40 \%)$ dan pengetahuan baik sebesar 12 orang $(36,40 \%)$, 2).Sikap responden tergolong kurang baik sebanyak 3 orang $(9,10 \%)$, cukup baik sebanyak 22 orang $(66,70 \%)$ dan sikap baik sebesar 8 orang $(24,20 \%), 3)$. Perilaku responden tergolong kurang baik sebanyak 9 orang $(27,30 \%)$, cukup baik sebanyak 13 orang $(39,40 \%)$ dan perilaku baik sebanyak 11 orang $(33,33 \%)$. Berdasarkan analisis diketahui terdapat hubungan yang signifikan pengetahuan dan sikap dengan perilaku masyarakat dalam pengendalian vektor demam berdarah dengue di Desa Jelok, Cepogo, Boyolali. dengan nilai korelasi dan probabilitas $\left(\mathrm{r}_{\mathrm{x} 1 \mathrm{y}}=\right.$ 0,$346 ; p_{1}=0,048$ dan $\left.r_{x 2 y}=0,393 ; p_{2}=0,024\right)$.

\section{SARAN}

Bagi masyarakat, diharapkan mengenali gambaran tanda-tanda dan gejala penyakit demam berdarah dengue sehingga dapat melakukan pengendalian vektor dan penekanan jumlah yang ada untuk mewujudkan kesehatan masyarakat. Bagi penyuluh kesehatan, diharapkan dapat menyusun strategi pemberantasan dan pencegahan terhadap penyakit demam berdarah dengue secara intensif. Bagi pengetahuan ilmu kesehatan, diharapkan dapat mengembangkan khasanah ilmu pengetahuan secara teoritis tentang ilmu-ilmu kesehatan yang dapat berguna bagi masyarakat secara umum dan penderita demam berdarah dengue secara khusus dalam rangka mengendalikan angka kejadian demam berdarah dan upaya untuk menurunkan resiko terjadinya penyakit demam berdarah. Hasil penelitian ini menjadi masukan untuk mengembangkan menjadi penelitian yang lebih luas, peneliti selanjutnya hendaknya menambah variabel-variabel lain tentang perilaku bagi penelitian selanjutnya masyarakat dalam pengendalian vektor demam berdarah dengue, selanjutnya untuk meminimalkan terjadinya bias dalam pengumpulan data. Hendaknya peneliti selanjutnya menambahkan metode pengumpulan datanya dengan observasi, dimana hasil observasi tersebut dapat menjadi pembanding kevalidan data yang diperoleh melalui kuesioner, serta menggunakan rancangan selain cross sectional misalnya dengan kohort maupun case control.

\section{DAFTAR PUSTAKA}

Balitbang Kemenkes RI.2018. Hasil Utama Riskesdas 2018. Jakarta: Web : http://www.kemkes.go.id. Diakses tanggal 10 Februari 2020

Budiman dan Riyanto, Agus. 2013. Kapita Selekta Kuesioner Pengetahuan dan Sikap Dalam Penelitian Kesehatan. Jakarta: Salemba Medika. 
Dinkes Kabupaten Boyolali, 2015. Profil Kesehatan Kabupaten Boyolali.

Ditjen P2P, KemenKes. RI. 2018. Petunjuk Teknis Pemberantasan Nyamuk Menular Penyakit Demam Berdarah Dengue. Jakarta : KemenKes. RI.

Fitriani NL dan Andriyani S. 2015. Hubungan Antara Pengetahuan Dengan Sikap Anak Usia Sekolah Akhir (10-12 Tahun) Tentang Makanan Jajanan Di Sd Negeri Ii Tagog Apu Padalarang Kabupaten Bandung Barat Tahun 2015. Jurnal Pendidikan Keperawatan Indonesia. Vol. 1. No. 1 (7-26).

Handayani S dan Setyawan F. 2015. Hubungan Pengetahuan dengan Sikap Seks Pranikah Pada Siswa SMAN 1 Kandanghaur Indramayu. Jurnal Kesehatan Masyarakat, Vol. 1, No. 2 Agustus 2015.

Heni Prasetyowati, Hubullah Fuadzy, Endang Puji Astuti. 2018. Pengetahuan, Sikap dan Riwayat Pengendalian Vektor di Daerah Endemis Demam Berdarah Kota Bandung, Bandung : Loka Litbang Kesehatan Pangandaran (diakses Tanggal 23 Maret 2020 Jam 23.39).

Kesehatan,K\&Indonesia,R. 2014. Profil Kesehatan Indonesia (M.S. dkk Yudianto, SKM,Ed. Jakarta: Web: http://www.kemkes.go.id. Diakses tanggal 10 Februari 2020

Listyorini PI. 2016. Faktor-Faktor yang Mempengaruhi Perilaku Pemberantasan Sarang Nyamuk (PSN) pada Masyarakat Karangjati Kabupaten Blora. INFOKES. 2016;6(1).

Notoadmodjo, Soekidjo. 2012. Metodologi Penelitian Kesehatan Edisi Revisi. Jakarta: PT. Rineka Cipta.

Nursalam. 2011. Konsep dan Penerapan Metodologi Ilmu Keperawatan. Jakarta : Salemba Medika

Oginawati, Lini Ariva, Katharina. 2013. Identifikasi Density Figure dan Pengendalian Vektor Demam Berdarah pada Kelurahan Cicadas Bandung ; Available from: http://publikasi.ftsl.itb.ac.id/assets/repositori/2013_10_19/2/1_2_153090 44_berkas.pdf. (diakses tanggal 23 Maret 2020 jam 23.39)

Ristiyanto, Heriyanto, Handayani, Trapsilowati, Pujiati dan Nugroho. 2013. Studi Pencegahan Penularan Leptospirosis di Daerah Persawahan di Kabupaten Bantul, Daerah Istimewa Yogyakarta. Jurnal Vektora Vol. V No. 1, Juni 2013.

Sari SM dan Ismail. 2012. Faktor-Faktor Yang Mempengaruhi Pengetahuan Siswa-Siswa Tentang HIV/AIDS di SMIT Negeri Kota Banda Aceh. Diakses dari http://ejournal.uui.ac.id/jurnal/SHINTA_MAYA_SARI23u-jurnal_shinta_maya_s.pdf

Setiadi. 2013. Konsep dan Penulisan Riset Keperawatan. Yogyakarta: Graha Ilmu. 
Wijaya, Andra Safera \& Putri Yessi Marisa,. 2013. KMB 2 Keperawatan Medikal Bedah (Keperawatan Dewasa). Yogyakarta: Nuha Medika 